\title{
Analisis kadar fibrinogen sebagai biomarker diabetik pada tikus wistar yang diinduksi streptozotocin
}

\author{
Imron Rosyadi*, Ella Romadhona, Ajeng Tyas Utami, Yayik Nur Hijrati, \\ Christin Marganingsih Santosa.
}

Departemen Patologi Klinik, Fakultas Kedokteran Hewan, Universitas Gadjah Mada, Yogyakarta

\begin{abstract}
ABSTRAK: Penyakit diabetes mellitus adalah serangkaian proses penyakit yang bermula dari kerusakan jaringan terutama di pankreas dimana awalnya ditandai dengan munculnya protein fase akut. Pada mamalia, konsentrasi protein fase akut yang dominan adalah serum amyloid A protein, $C$-reaktive protein dan fibrinogen. Penelitian ini bertujuan untuk mencari korelasi protein fase akut fibrinogen untuk digunakan sebagai biomarker pada tikus diabetes yang diinduksi streptozotocin. Tikus yang digunakan adalah tikus Wistar jantan sebanyak 20 ekor, umur sekitar 2 bulan dengan berat badan 180-250 gram. Tikus dibagi menjadi dua kelompok, masing-masing kelompok 10 ekor tikus sebagai kelompok induksi dan kelompok kontrol. Kelompok induksi dipuasakan selama 24 jam kemudian diinjeksi streptozotocin 1 kali dengan dosis $40 \mathrm{mg} / \mathrm{kg}$ bb yang dilarutkan dalam bufer sodium sitrat $0,1 \mathrm{M} \mathrm{pH}$ 4,0. Tikus diambil darah pada jam ke-0, 6, 12, 24, 48, 60, 72, 84 dan 96 post induksi diabetes untuk diperiksa kadar konsentrasi protein fase akut fibrinogen Hasil penelitian rata-rata kadar fibrinogen pada jam ke-0 dan ke-6 yaitu sebesar $0,57 \pm 0,06 \mathrm{mg} / \mathrm{mL}$ dan $0,60 \pm 0,35 \mathrm{mg} / \mathrm{mL}$ masih dalam range normal, kemudian mulai meningkat terus berturut-turut di jam ke-12 sebesar 0,6 $\pm 0,4 \mathrm{mg} / \mathrm{mL}$, jam ke-24 0.93 $\pm 0,46 \mathrm{mg} / \mathrm{mL}$, jam ke-36 1,1 $\pm 0,1 \mathrm{mg} / \mathrm{mL}, \mathrm{jam} \mathrm{ke}-48$

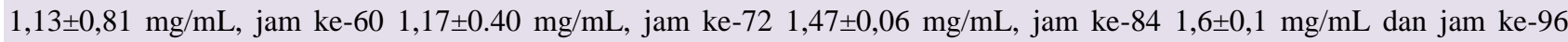
$1,8 \pm 0,1 \mathrm{mg} / \mathrm{mL}$. Hasil dari penelitian ini menunjukkan protein fase akut fibrinogen dapat dijadikan sebagai salah satu marker pada tikus yang diinduksi diabetes mellitus.

Kata kunci:

diabetes, fibrinogen, protein fase akut, tikus wistar
\end{abstract}

\section{- PENDAHULUAN}

Penyakit diabetes mellitus adalah penyakit yang bermula dari kerusakan jaringan terutama di pankreas. Penyakit diabetes mellitus pada awalnya ditandai dengan keberadaan protein fase akut (Murata, 2004). Respon protein fase akut adalah reaksi spesifik dan kompleks organisme yang terjadi tidak lama setelah terjadi cedera pada jaringan (Tóthová et al., 2013). Fibrinogen merupakan reaktan fase akut, dan kadarnya akan meningkat dua sampai sepuluh kali lipat dari normal sebagai respon terhadap keadaan stres fisiologi, termasuk trauma, kehamilan, dan inflamasi jaringan (Kofoed et al., 2003). Fibrinogen juga berfungsi membentuk bekuan darah pada proses koagulasi dan viskositas darah (Rothwell et al., 2004; Cucchiara, 2009). Penelitian ini bertujuan untuk mencari korelasi protein fibrinogen fase akut sebagai kandidat biomarker pada tikus diabetes yang diinduksi streptozotocin.

\section{- BAHAN DAN METODE}

Tikus jenis Wistar sebanyak 10 ekor berjenis kelamin jantan, umur sekitar 2 bulan, dengan berat badan 180-250 gram digunakan dalam penelitian ini. Tikus diperoleh dari Laboratorium Farmakologi dan Toksikologi, Fakultas Farmasi, Universitas Gadjah Mada, Yogyakarta. Streptozotocin dari Nakalai, Japan dan sodium sitrat bufer sebagai pelarut dari Laboratorium Patologi Klinik, Fakultas Kedokteran Hewan, Universitas Gadjah Mada, Yogyakarta digunakan dalam penelitian ini. Tikus diberikan minum dan pakan secara ad libitum, dan bedding berupa serutan kayu yang telah dioven sebelumnya.

Tikus dibagi menjadi dua kelompok, yaitu kontrol sebanyak 10 ekor tikus dan induksi sebanyak 10 ekor tikus. Kelompok induksi dipuasakan selama 24 jam kemudian diinjeksi streptozotocin 1 kali dengan dosis $40 \mathrm{mg} / \mathrm{kg}$ bb dalam bufer sodium sitrat $0,1 \mathrm{M}$ pH 4,0. Tikus diambil darah sebanyak $1 \mathrm{~mL}$ dari vena plexus retroorbitalis pada jam ke-0, 6, 12, 24, 48, 60, 72, 84 dan 96 post induksi diabetes untuk diperiksa kadar konsentrasi protein fase akut.

Pengukuran konsentrasi protein fase akut fibrinogen dilakukan dengan menghitung antara Total Protein Plasma (TPP) sebelum dan setelah dipanaskan pada suhu $58{ }^{\circ} \mathrm{C}$ selama 3 menit (Imron, 2016). Data hasil penelitian dianalisa secara statistik dengan Annova dan dibandingkan secara deskriptif diantara kelompok.

Diterima: 30-09-2017 | Direvisi: 03-11-2017 | Disetujui: 14-11-2017 (C) 2018 CC-BY-SA. Ini adalah artikel Open Access yang didistribusikan berdasarkan ketentuan dari Creative Commons Attribution ShareAlike 4.0 International License (https://creativecommons.org/licenses/by-sa/4.0/). 


\section{- HASIL DAN PEMBAHASAN}

Hasil rata-rata pengukuran kadar fibrinogen tikus pascaperlakuan (Gambar 1). Hasil rata-rata nilai total leukosit pada kelompok induksi pada jam ke-0, 6 dan 12 masih berkisar dalam range normal yaitu sebesar $0,57 \pm 0,06-$ $0,60 \pm 0,40 \mathrm{mg} / \mathrm{ml}$. Kemudian mengalami kenaikan pada jam ke-24 menjadi 0,93 $\pm 0,46 \mathrm{mg} / \mathrm{ml}$. Kenaikan ini berlangsung secara stabil dan berturut-turut hingga jam ke-96 yaitu

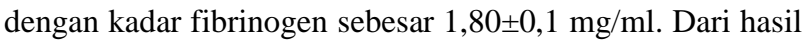
analisis statistik menunjukkan adanya perbedaan yang signifikan $(\mathrm{p}<0,05)$ pada saat jam ke-0,6,12 dengan pada jam ke 24, 48, 60, 84 serta 96. Hal ini menunjukkan kadar fibrinogen meningkat seiring dengan induksi dari streptozotocin menuju ke proses diabetes.

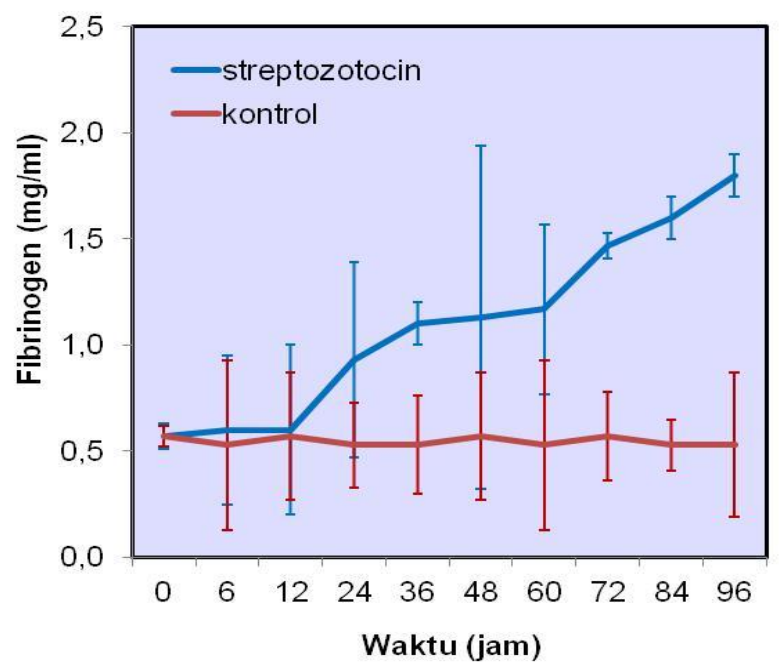

Gambar 1 Kadar fibrinogen fase akut pada tikus Wistar pascainduksi streptozotocin.

Tikus pada kelompok normal (kontrol), rata-rata kadar fibrinogennya tidak menunjukkan adanya peningkatan atau penurunan yang signifikan. Terlihat pada jam ke-0 hingga 96 berkisar diantara 0,53 $\pm 0.12-0,57 \pm 0.4 \mathrm{mg} / \mathrm{ml}$. Dari hasil analisis statistik menunjukkan tidak adanya perbedaan yang signifikan $(p>0,05)$ kadar fibrinogen dari jam ke-0 hingga 96 dalam kelompok tikus normal. Hal ini menunjukkan kadar fibrinogen kelompok kontrol dapat dijadikan acuan normal kadar fibrinogen.

Hasil uji statistik menunjukkan bahwa tidak adanya perbedaaan kadar fibrinogen yang signifikan $(p>0,05)$ pada jam ke 0,6 dan 12 antara kelompok perlakuan. Tetapi, pada jam ke 24 hingga 96 ada perbedaan peningkatan kadar fibrinogen yang signifikan $(\mathrm{p}<0,05)$ diantara kelompok. Hal ini menunjukkan bahwa pada kelompok tikus yang diinduksi diabetes telah terjadi peningkatan kadar fibrinogen akibat dari induksi diabetes melitus dengan streptozotocin (Miller \& Baker, 1972).

Hasil pengukuran kadar fibrinogen ini sebanding dengan hasil pengukuran kadar gula dalam darah pada tikus yang diinduksi streptozotocin. Pada jam ke 0 dan 6 post induksi, tikus masih dalam keadaan normal. Hal ini terlihat dari hasil kadar gula darah dan kadar fibrinogen yang masih dalam ambang normal. Namun pada jam ke 12 dimana terjadi penurunan kadar gula darah secara signifikan, kadar fibrinogen juga mulai perlahan meningkat. Hasilnya pada jam ke 24 tikus sudah mengalami hiperglikemia, kadar fibrinogennya pun meningkat (Napoli \& Singh, 2009).

\section{- SIMPULAN}

Hasil penelitian menunjukkan bahwa peningkatan kadar fibrinogen sejalan dengan proses terjadinya diabetes pada tikus yang diinduksi streptozotocin. Dengan demikian, maka fibrinogen dapat menjadi salah satu marker pada tikus yang diinduksi diabetes dengan streptozotocin.

\section{- INFORMASI PENULIS}

Penulis untuk Korespondensi

*IR: imron.rosyadi@ugm.ac.id

Departemen Patologi Klinik, Fakultas Kedokteran Hewan, Universitas Gadjah Mada, Yogyakarta

J1. Fauna No. 2 Karangmalang, Yogyakarta 55281 Indonesia

\section{- PUSTAKA ACUAN}

Cucchiara BL. 2009. Evaluation and management of stroke. ASH Education Program Book, 2009(1):293-301.

Imron R. 2016. Potensi anti diabetes melitus serbuk umbi tanaman sarang semut (Myrmecodia tuberose) melalui kajian hematologik, imunologik dan histopatologik organ tikus wistar yang diinduksi streptozotocin. Thesis Magister Sain Veteriner, Fakultas Kedokteran Hewan UGM.

Kofoed SC, Wittrup HH, Sillesen H, Nordestgaard BG. 2003. Fibrinogen predicts ischaemic stroke and advanced atherosclerosis but not echolucent, rupture-prone carotid plaques: the Copenhagen city heart study. European Heart Journal. 24(6):567-576.

Miller ME, Baker L. 1972. Leukocyte functions in juvenile diabetes mellitus: humoral and cellular aspects. The Journal of Pediatrics. 81(5):979-982.

Murata H, Shimada N, Yoshioka M. 2004. Current research on acute phase proteins in veterinary diagnosis: an overview. The Veterinary Journal. 168(1):28-40.

Napoli MD, Singh P. 2009. Is plasma fibrinogen useful in evaluating ischemic stroke patients? why, how, and when. Stroke: 40: 1549-1552.

Rothwell PM, Howard SC, Power DA, Gutnikov SA, Algra A, van Gijn J, Clark TG, Murphy MFG, Warlow CP.. 2004. Fibrinogen concentration and risk of ischemic stroke and acute coronary events in 5113 patients with transient ischemic attack and minor ischemic stroke. Stroke. 35: 2300- 2305. DOI:10.1161/01.STR.0000141701.36371.d1

Tóthová C, Nagy O, Kováč G. 2013. The use of acute phase proteins as biomarkers of diseases in cattle and swine. In: Acute Phase Proteins. Intech. http://dx.doi.org/10.5772/55857. 